\title{
The Impact of Social Media Usage on Marketing Performance via Innovation: An Empirical Study on Service Firms in Egypt
}

\author{
Dr. Heba Sadek Dr. Passent Tantawi \\ Arab Academy for Science, Technology and Maritime Transport Alexandria, Egypt \\ *Email of the corresponding author: hebahassan@aast.edu
}

\begin{abstract}
With the growing intensified competition and development of the service sector, innovation has become vital dimension for firms to enjoy competitive advantages and yield positive outcomes on the economy. The use of social media (SM) as one of the service firm communication tools fosters innovation and has always been of critical importance to both academia and practice. Thus, this study focuses on the impact of SM usage based on both knowledge exploration and exploitation on the marketing performance via the most widely accepted four innovation types in past literature, which consist of product, process, marketing and organizational innovation in the Egyptian private service sector. Questionnaires were distributed electronically to gather data. Data gathered from 385 private service firms from the top management level. Data has been analyzed via Structural Equation Modelling (SEM), AMOS 22. Results indicated that SM usage has a significant positive direct impact on all types of innovation with varying relative effects. Additionally, it has been found that marketing innovation played the greatest direct and positive impact on the marketing performance, followed by the product innovation, however, the process innovation has been found to have negative impact on the marketing performance. While the organizational innovation does not directly impact the marketing performance. This study contributes to the literature by highlighting on the SM usage and the vital types of innovation that lead to higher marketing performance in the service sector which needs more attention from service marketing managers. Also, this study helps the service providers in the private service firms to focus on the significance role of SM in exploring and exploiting knowledge especially from customers to innovate in a better way to consequently enhance the marketing performance.
\end{abstract}

Keywords: social media, innovation, marketing performance, service sector, Egypt

DOI: $10.7176 / \mathrm{JAAS} / 75-03$

Publication date:August $31^{\text {st }} 2021$

\section{Introduction}

The business environment has been undergoing vibrant changes over the past twenty years especially with the use of social media (SM) and innovation (Freixanet et al., 2021). Innovation has been an indicator for success for business firms, affecting the business and marketing performance and driving the firm's growth (Aksoy, 2017). Innovation consists of four main categories which are related to product outcome (service or goods), process, marketing and organizational innovation. With a blend of these four components, firms can achieve uniqueness, have lower sensitivity to price and gain more profits (Afriyie et al., 2019). Hence, with the growing power of customers as active partners (Rosenbaum et al., 2017) and severity of today's business competition, marketing managers are increasingly recognizing the need for innovation for developing their firms and possessing relative competitive strengths (Bhimani et al., 2019; Bhatti et al., 2021).

The growth and progressing of the service sector urged firms to seize the innovation opportunities especially those with great social and economic effect. This has become an interest for scholars in the organizational research field (Ferraz \& Santos, 2016). Service firms are increasingly recognizing the critical role played by innovation in the societal and economic progression (Ferraris et al., 2017). Therefore, innovation supports service firms in improving their performance, generally during the difficult time of Covid-19 crisis, and help them survive (Ando, 2021) and one of the unsurpassed and influential communication tools which leads to nurturing innovation is the SM usage (Mention et al., 2019).

With the use of social media (SM), customers may initiate several firms' products and can also participate in the process of firms' innovation (Payne et al., 2008). This is due to the ability of SM in allowing the exchange of information through user generated contents since it includes web 2.0 applications' technology and ideology (Kaplan \& Haenlein, 2010). According to Mention et al. (2019), SM support firms' innovation and the prompt transfer of information in various ways and shapes, for example, via free voices and immediate messaging with customers help to increase the coordination between firms and their customers and created chances for having innovative ideas. Thus, firm's marketing managers need to explore and exploit the shared knowledge on SM to undertake specific actions based on that to compete successfully (Alrowwad et al., 2020).

Nevertheless, there is an immense growth of SM among several firms, there are limited researches which investigate the role of SM usage based on knowledge exploration and exploitation and its consequences based on employees' perspective (Parveen et al., 2016; Hameed et al., 2018). Hardwick and Anderson (2019) and 
Freixanet et al. (2021) mentioned that research about firms involved in innovation and SM usage is still unclear and lacking the empirical side and requires future investigations. Also, Corral de Zubielqui and Jones (2020) urged the need for measuring the impact of innovation and marketing performance. In accordance with this thought of inquiry, this research aims to measure the impact of SM usage (knowledge exploration and exploitation) on innovation (including all of its four types) and marketing performance from the employees' perspectives in service firms.

\section{Theoretical Background and Hypotheses Development}

\subsection{SM and Innovation}

Social media get stakeholders, firms, users and societies together. They have become a part of the daily activities performed by individuals and businesses (Dwivedi et al., 2020). Firms are progressively recognizing their importance in communicating and engaging stakeholders and fostering innovation (Mention et al., 2019). On a massive scale, social media platforms provide cost effective techniques to the generation and use of innovative ideas, experiences and solutions. They demonstrate a feedback platform for better ideas, effective communication and networking with stakeholders (Oyewobi et al., 2020). Therefore, firms can make use of SM users' ideas and generated contents to better improve and innovate their services and products (Patroni et al., 2020). Consequently, this study is based on SM usage that is described as the ability of firm's to use SM in order to predict and find innovative ideas (knowledge exploration) and to execute and apply them (knowledge exploitation) (Kiron et al., 2013 and Freixanet et al., 2021).

Such knowledge and ideas form the main contributors in innovation that will possibly lead to better developments (Frexinat et al., 2021). Therefore, SM usage follows the Resource-based-view theory "RBVT" which emphasized on the role of firms' internal resources (characteristics, processes, assets, knowledge, and capabilities) and also in adopting selected strategies to gain competitive advantage and achieve a balance between efficiency and effectiveness in their operations (Barney, 1991, p. 101; Marchant et al., 2020). Firms differ in the resources they own (such as SM resources) which may significantly contribute to their failure or success, limit their access to the market or affect their marketing performance (Kozlenkova et al., 2013). SM resources may be perceived as major obstacles to some firms who can not well- communicate and manage their brands with stakeholders and may not be able to respond to customers' complaints (Herhausene et al., 2019). They are vital platforms for fast sharing of information especially about firms' new market offers and for stimulating the engagement of customers in the innovation activities. They support firms in the acquisition and sharing of knowledge, getting innovative ideas and better interacting with competitors, stakeholders and community at large (Perez-Gonzalez et al., 2017; Zhang et al., 2020).

Previous studies such as Dong and Wu study (2015) and Frexinat et al. (2021) indicated the significance of $\mathrm{SM}$ in improving the value of information through using the user-generated ideas to develop new ideas and take corrective actions in the innovation. Based on Oslo manual OECD (Organization for Economic Cooperation and Development) (2005), innovation includes four types namely; product, process, marketing and organizational innovation. Product innovation is described as any improvements in the product or service (Zaefarian et al., 2017). Process innovation means any developments related to the production process (Dost et al., 2020). Marketing innovation is defined as new marketing methods (Hassan et al., 2013). Organizational innovation means new workplace regulations (Polder et al., 2010). Thus, in line with these prior studies, this study will test the impact of SM on all innovation types as presented in the following hypotheses:

H1: The SM usage has a significant positive impact on product innovation

$\mathrm{H} 2$ : The SM usage has a significant positive impact on process innovation

H3: The SM usage has a significant positive impact on marketing innovation

H4: The SM usage has a significant positive impact on organizational innovation

\subsection{Innovation and Marketing performance}

According to Anning-Dorson (2017) and Gupta (2021) innovation differentiates between firms and can create the firm's competitive advantage, foster its growth and supports some firms' survival while develop other firms to be leaders in the market. Innovation has a growing pervasiveness in the business due to its contribution to firm's competitiveness particularly in the service sector (Buenechea-Elberdin, 2017). Innovation management is about presenting a firm's creative new goods, services, processes, ideas and marketing techniques which distinguish it from the competitors (Gupta, 2021).

The four innovation types, which include product, process, marketing and organizational innovation have significant impact on the market performance and offer firms several benefits related to customer services developments (Oslo manual OECD, 2005). In more details, product innovation is related to utilitarian benefits related to enhancing goods and services (Aksoy, 2017; Afriyie, 2019; Zaefarian et al., 2017). Also, process innovation entails using new and innovative techniques in conducting the businesses (Akgün et al., 2013, Dost et al., 2020). The innovation in marketing involves employing new marketing techniques to bring about major 
modifications in the promotion, packaging, placement and pricing strategies (Hassan et al., 2013). According to Polder et al. (2010), organizational innovation involves the introduction to a new work and environmental conditions, regulations, and decision-making, and new approaches to handling external relations. This study in line with previous studies of follows the classification of OECD of innovation and considers that the firm's innovation is a key element of marketing performance.

According to Oslo manual OECD (2005), one of the critical forms of innovation is product innovation which includes making modification and radical improvements in the firm's functional products and services' attributes. There is a positive relationship between product innovation and firm's performance. Product innovation is the most prominent kind of innovation mentioned in past literature due to its strategic significance in adapting with market trends (Vaona \& Pianta, 2007) and great impact on the firms' marketing performance (Varis \& Littunen, 2010). Also, Datta (2011) indicated that effective product innovation strategies yield revenues, help firms to enlarge their market shares and positively affect the firm's marketing performance. Product innovation involves presenting novel goods and services with respect to their new features and utilities, new product lines expansion, new customized offerings according to target market needs and wants (Atalay et al., 2013). It provides high customer value and supports firms' growth opportunities which yield a positive impact on the firm's marketing performance. Thus, the following hypothesis is developed:

H5: There is a significant positive impact of product innovation on the firm's marketing performance

Process Innovation encompasses the implementation of a new value-added successions of a firm's activities. Largely, it means innovation related to the production methods inside the firm (Dost et al., 2020). Extensively, process innovation varies in scope and nature from one firm to another. It necessitates full comprehension of the firm's processes (Lager, 2017) and includes huge developments in the firm's procedures, tasks, and activities that could be shown in the firms' advanced tools, equipment, and software for ensuring and implementing quality (Gunday et al., 2011). Process innovation has positively affected the firms' marketing performances (Gupta, 2021). Therefore, the following hypothesis is developed:

H6: There is a significant positive impact of Process innovation on the firm's marketing performance

According to Dost et al. (2020), innovation and marketing are well connected. Marketing innovation may include various changes in design, positioning, branding and pricing of products and services. Some factors such as innovative distribution channels and communication tools, and new market and customer data extraction and analysis are examples of marketing innovation (Hammer, 2004). This is because marketing innovation should include evaluating customers' perceptions to understand the unmet customer needs and create opportunities for the firms' new products and services to meet those needs (Kohlbacher, 2013) and generate high marketing performance and customer value (Afriyie et al., 2019; Wang et al., 2020). Thus, this hypothesis is developed as follows:

H7: There is a significant positive impact of Marketing innovation on the firm's marketing performance

Organizational innovation means all firm's procedures which makes innovation an essential and built-in component of its management regulations such as modifications in the management and human resources systems and improvements in the customer-suppliers relationships (Polder et al., 2010). Previous studies indicated that organizational innovation positively impacts the firm's marketing performance in varies industries and services (Yeh-Yun Lin \& Yi-Ching Chen, 2007). Therefore, the following hypothesis is developed:

H8: There is a significant positive impact of Organizational innovation on the firm's marketing performance.

Based on the previous studies, the following research model is presented below

Figure (1): The Research Conceptual Framework

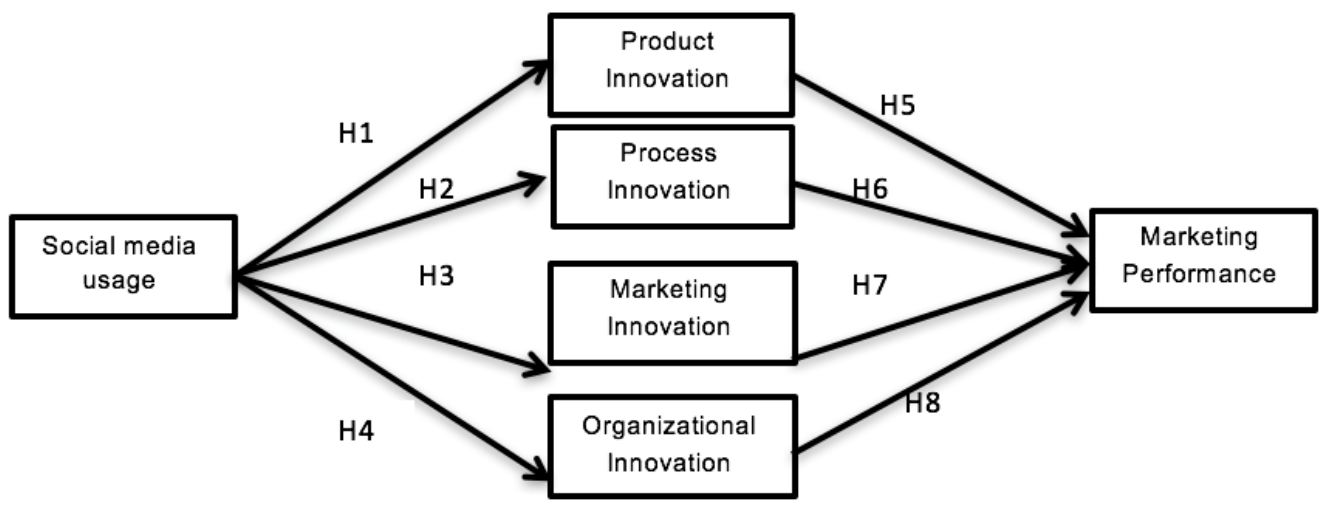

\section{Methodology}

A quantitative study has been conducted to examine the impact of social media usage (knowledge exploration and knowledge exploitation) on marketing performance via innovation (product, process, marketing and 
organizational innovation) in the private service sector in Egypt where there is a severe market competition from one side and from the other side, innovativeness in services is connected with their growing role in the economy. Innovation is seen as an essential link in developing a strong economy. Predominantly in the private sector, which contributes by $84.5 \%$ in the total production and contributes by $86.4 \%$ in the gross value added in the Egyptian economy (CAPMAS, 2021).

The researchers used an online survey format, which was distributed based on a convenience sampling technique to 530 firms targeted the top management level in the private service sector such as: education, banking, insurance, information and communication, real estate, healthcare, transportation, etc. mainly in Cairo and Giza, since the highest percentage of the private firms were found in Cairo governorate at first and second in Giza governorate according to CAPMAS (2021). The response rate was $73 \%$ as only 385 firms have responded and completed the electronic questionnaires due to the limited time of the top management level.

Based on the data collected, the researchers were able to test the research hypotheses via the structural equation modelling (SEM), AMOS 22. The questionnaire consisted of three main parts based on five point Likert scale and the last part was about respondents' characteristics. The first part was about the social media usage in the private service sector that consists of knowledge exploration and knowledge exploitation. The scale items of social media usage consisted of 7 items that were adapted from Freixanet et al. (2021). The second part was about innovation, which comprised (product, process, marketing and organizational innovation). The scale items of the 4 types of innovation included 21 items that were adapted from Afriyie (2019). The third part was about marketing performance included 9 items that were adapted from Khan and Khan (2021).

\section{Results and Analysis}

The Structural Equation Modelling (SEM) was done based on AMOS 22. First of all, descriptive statistics for the sample unit have been presented. Next, convergent validity and reliability analysis, discriminant validity, and measurement model fit indices have been measured before testing the research hypotheses.

\subsection{Descriptive Statistics for the Research Sample}

The sample size was 385 firms in the Egyptian private service sector. The employees who responded to the survey were from top management level, $45.5 \%$ female and $54.5 \%$ male and $75 \%$ of the sample were above 40 years old. The 385 firms were from different service industries such as banking, computer services, education, health, media, telecommunication, etc. The size of the firms ranges from $<10$ employees to $>250$ employees.

\subsection{Convergent Validity and Reliability Analysis}

Explanatory factor analysis (EFA) was used to measure the convergent validity. From table (1), the EFA was evaluated based on the principal component analysis. Factor loadings of 0.5 or more are significant for sample sizes of 350 or greater (Hair et al., 2014). Further, Kaiser- Meyer-Olkin (KMO) and Bartlett's Test were evaluated as shown in table (1). According to Hair et al. (2010), KMO returns values are between 0 and 1 and the values closer to 1 are better. Moreover, a significant Bartlett's test of sphericity is required while $p$ is less than 0.05 (Bartlett, 1951). In addition, the EFA was used to notice the unidimensionality of each construct. Unidimensionality is an indication that a single construct underlies a set of measures (Anderson \& Gerbing, 1988). The unidimensionality was stated by the Average Variance Extracted (AVE) that must be greater than $50 \%$ (Hair et al., 2010).

Besides, the reliability test was measured because it identifies the degree to which a scale produces consistent results if measurements are done repetitively and according to Hair et al. (2014), the Cronbach's alpha greater than 0.7 shows a good level of reliability. In this paper and as shown in table (1), the shaded items have been deleted in order to improve the validity and reliability of the scales, where the loading coefficient of these items were less than 0.6 and by excluding them, the KMO has been improved to be more than 0.5, the Bartlett's test is becoming significant and the AVE\% has been adjusted to be greater than $50 \%$. In addition, the reliability coefficients of Cronbach's alpha have been enhanced to exceed 0.7 . 
Table (1): Convergent Validity and Reliability Analysis

\begin{tabular}{|c|c|c|c|c|c|c|c|}
\hline \multirow{2}{*}{\multicolumn{2}{|c|}{ Construct }} & \multirow[b]{2}{*}{ Items } & \multicolumn{4}{|c|}{ Convergent Validity } & \multirow[b]{2}{*}{ 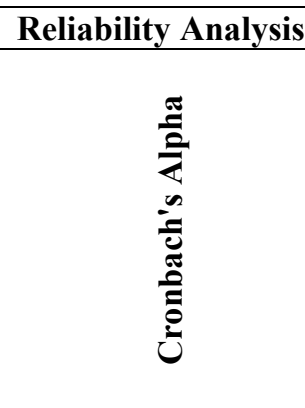 } \\
\hline & & & 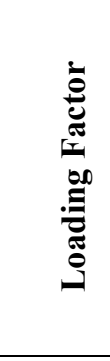 & 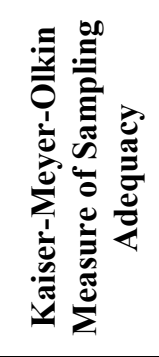 & 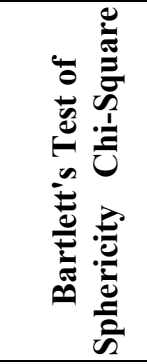 & 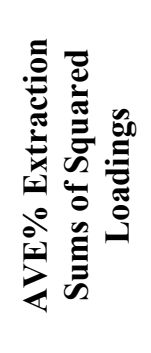 & \\
\hline \multirow{7}{*}{\multicolumn{2}{|c|}{ 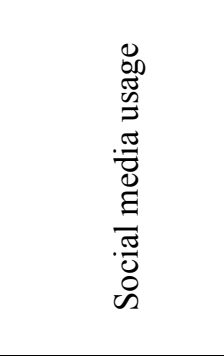 }} & Q_1 & 0.788 & \multirow{7}{*}{0.852} & \multirow{7}{*}{$\begin{array}{c}926.874 \\
(0.000)\end{array}$} & \multirow{7}{*}{51.399} & \multirow{7}{*}{0.839} \\
\hline & & Q_2 & 0.698 & & & & \\
\hline & & Q_3 & 0.823 & & & & \\
\hline & & Q_4 & 0.658 & & & & \\
\hline & & Q_5 & 0.751 & & & & \\
\hline & & Q_6 & 0.604 & & & & \\
\hline & & Q_7 & 0.689 & & & & \\
\hline \multirow{21}{*}{ 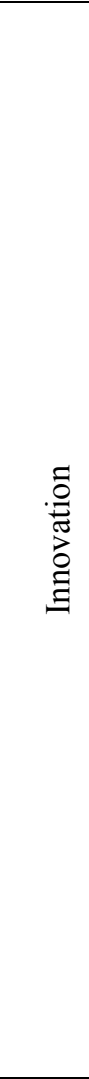 } & \multirow{4}{*}{ 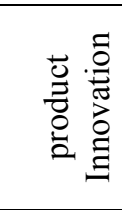 } & Q_8 & 0.634 & \multirow{4}{*}{0.625} & \multirow{4}{*}{$\begin{array}{c}411.464 \\
(0.000)\end{array}$} & \multirow{4}{*}{55.891} & \multirow{4}{*}{0.734} \\
\hline & & Q_9 & 0.739 & & & & \\
\hline & & Q_10 & 0.799 & & & & \\
\hline & & Q_11 & 0.805 & & & & \\
\hline & \multirow{4}{*}{ 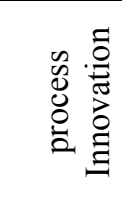 } & Q_12 & 0.887 & \multirow{4}{*}{0.5} & \multirow{4}{*}{$\begin{array}{c}153.363 \\
(0.000)\end{array}$} & \multirow{4}{*}{78.737} & \multirow{4}{*}{0.73} \\
\hline & & Q_13 & 0.887 & & & & \\
\hline & & Q_14 & 0.39 & & & & \\
\hline & & Q_15 & 0.384 & & & & \\
\hline & \multirow{8}{*}{.ఃี } & Q_16 & 0.798 & \multirow{8}{*}{0.814} & & & \\
\hline & & Q_17 & 0.707 & & & & \\
\hline & & Q_18 & 0.597 & & & & \\
\hline & & Q_19 & 0.66 & & 1204.573 & 55064 & 0862 \\
\hline & & Q_20 & 0.736 & & $(0.000)$ & 3.004 & 0.002 \\
\hline & & Q_21 & 0.747 & & & & \\
\hline & & Q_22 & 0.759 & & & & \\
\hline & & Q_23 & 0.777 & & & & \\
\hline & & Q_24 & 0.626 & & & & \\
\hline & ฮี . & Q_25 & 0.627 & & & & \\
\hline &.$\sqrt[\tilde{N}]{\approx} \frac{\pi}{3}$ & Q_26 & 0.733 & 0.731 & $\begin{array}{l}667.192 \\
(0.000)\end{array}$ & 55.187 & 0.781 \\
\hline & 馬 & Q_27 & 0.861 & & & & \\
\hline & & Q_28 & 0.834 & & & & \\
\hline & & Q_29 & 0.811 & & & & \\
\hline & & Q_30 & 0.922 & & & & \\
\hline & 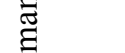 & Q_31 & 0.881 & & & & \\
\hline & 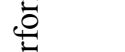 & Q_32 & 0.855 & & & & \\
\hline & $\stackrel{0}{2}$ & Q_33 & 0.836 & 0.855 & $\begin{array}{c}1 / 62.996 \\
(0000)\end{array}$ & 69.814 & 0.912 \\
\hline & $\Xi$ & Q_34 & 0.585 & & & & \\
\hline & $\stackrel{\mathscr{y}}{\exists}$ & Q_35 & 0.533 & & & & \\
\hline & $\Sigma$ & Q_36 & 0.592 & & & & \\
\hline & & Q_37 & 0.689 & & & & \\
\hline
\end{tabular}




\subsection{Discriminant Validity}

To assess the discriminant validity of research variables, the square root of AVE for each variable was compared with its correlation with other variables (Sharma \& Patterson, 1999). As shown in table (2), comparisons were done among square root of AVE (internal correlations) for each variable and its correlation coefficients with other variables. Based on the comparisons, significant correlations exist between research variables, but all these correlations are lower than the square root of AVE. For example, social media usage and marketing innovation are correlated $(\mathrm{r}=0.643)$, but the square roots of AVE of both variables are 0.717 and 0.742 , respectively. This means that respondents can discriminate between both variables while they are correlated. By examining this matrix, it has been found that respondents can discriminate between all research variables.

Table (2): Correlations \& Internal Correlations

\begin{tabular}{|c|c|c|c|c|c|c|c|}
\hline & AVE & $\begin{array}{l}\text { Social } \\
\text { media } \\
\text { usage }\end{array}$ & $\begin{array}{c}\text { Marketing } \\
\text { Performance }\end{array}$ & $\begin{array}{l}\text { product } \\
\text { Innovation }\end{array}$ & $\begin{array}{c}\text { process } \\
\text { Innovation }\end{array}$ & $\begin{array}{l}\text { marketing } \\
\text { Innovation }\end{array}$ & $\begin{array}{l}\text { organizational } \\
\text { Innovation }\end{array}$ \\
\hline $\begin{array}{l}\text { Social media } \\
\text { usage }\end{array}$ & 51.399 & 0.717 & & & & & \\
\hline $\begin{array}{l}\text { Marketing } \\
\text { Performance }\end{array}$ & 69.814 & 0.105 & 0.836 & & & & \\
\hline $\begin{array}{l}\text { product } \\
\text { Innovation }\end{array}$ & 55.891 & 0.348 & 0.265 & 0.748 & & & \\
\hline $\begin{array}{l}\text { process } \\
\text { Innovation }\end{array}$ & 78.737 & 0.508 & 0.014 & 0.311 & 0.887 & & \\
\hline $\begin{array}{l}\text { marketing } \\
\text { Innovation }\end{array}$ & 55.064 & 0.643 & 0.314 & 0.580 & 0.476 & 0.742 & \\
\hline $\begin{array}{l}\text { organizational } \\
\text { Innovation }\end{array}$ & 55.187 & 0.521 & 0.150 & 0.382 & 0.409 & 0.641 & 0.743 \\
\hline
\end{tabular}

Note: the shaded cells contain the square root of AVE (internal correlations)

\subsection{Model Fit Indices}

In order to analyze the hypothesized relationships via the SEM. The model fit indices should be checked. As shown in table (3) all values indicate an acceptable level of the good fit of the model based on Hair et al., (2010), for example the minimum discrepancy per degree of freedom (CMIN/DF), root mean square residual (RMR), comparative fit index (CFI), and root mean square error of approximation (RMSEA) are 3.74, 0.08, 0.931 and 0.071 respectively.

Table (3): Model Fit Indices

\begin{tabular}{|l|l|l|l|l|}
\hline & CMIN/DF & RMR & CFI & RMSEA \\
\hline SEM Model best result & $3.74-5$ & .08 & .931 & .071 \\
\hline $\begin{array}{l}\text { The (acceptable } \\
\text { according to Hair et } \\
\text { al., (2010) }\end{array}$ & Less than 10\% & $\begin{array}{l}\text { Range from 0 to } \\
1 \text { (closer to 1 is } \\
\text { better) }\end{array}$ & $\begin{array}{l}\text { Less than } \\
\text { acceptable and Less than } \\
0.05 \text { is good }\end{array}$ \\
\hline
\end{tabular}

\subsection{Testing the Research Hypotheses}

The AMOS output for the model parameter estimates is reflected in table (4). Based on Hair et al. (2010), any number of p-value less than 0.05 is significant in the model.

\section{Table (4): Direct Effects}

\begin{tabular}{|c|c|c|c|c|c|c|c|c|}
\hline $\begin{array}{l}\text { Number } \\
\text { Of } \\
\text { Hypotheses }\end{array}$ & & ct Ef & cts & 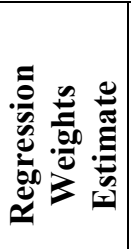 & $\mathbf{t}$ & $P_{-}$Value & 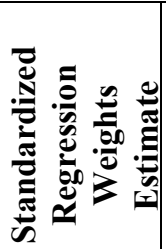 & Results \\
\hline H1 & $\begin{array}{l}\text { product } \\
\text { Innovation }\end{array}$ & $<---$ & $\begin{array}{l}\text { Social media } \\
\text { usage }\end{array}$ & 0.309 & 7.27 & $* * *$ & 0.348 & $\begin{array}{l}\text { Positive } \\
\text { significant } \\
\text { effect }\end{array}$ \\
\hline $\mathrm{H} 2$ & $\begin{array}{l}\text { process } \\
\text { Innovation }\end{array}$ & $<---$ & $\begin{array}{l}\text { Social media } \\
\text { usage }\end{array}$ & 0.587 & 11.547 & $* * *$ & 0.508 & $\begin{array}{l}\text { Positive } \\
\text { significant } \\
\text { effect }\end{array}$ \\
\hline
\end{tabular}




\begin{tabular}{|c|c|c|c|c|c|c|c|c|}
\hline $\begin{array}{l}\text { Number } \\
\text { Of } \\
\text { Hypotheses }\end{array}$ & \multicolumn{3}{|c|}{ Direct Effects } & 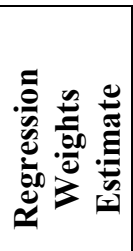 & $\mathbf{t}$ & P_Value & 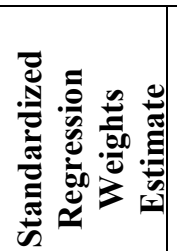 & Results \\
\hline H3 & $\begin{array}{l}\text { marketing } \\
\text { Innovation }\end{array}$ & $<--$ & $\begin{array}{l}\text { Social media } \\
\text { usage }\end{array}$ & 0.589 & 16.462 & $* * *$ & 0.643 & $\begin{array}{l}\text { Positive } \\
\text { significant } \\
\text { effect }\end{array}$ \\
\hline $\mathrm{H} 4$ & $\begin{array}{l}\text { organizational } \\
\text { Innovation }\end{array}$ & $<---$ & $\begin{array}{l}\text { Social media } \\
\text { usage }\end{array}$ & 0.534 & 11.952 & $* * *$ & 0.521 & $\begin{array}{l}\text { Positive } \\
\text { significant } \\
\text { effect }\end{array}$ \\
\hline H5 & $\begin{array}{l}\text { Marketing } \\
\text { Performance }\end{array}$ & $<---$ & $\begin{array}{l}\text { product } \\
\text { Innovation }\end{array}$ & 0.173 & 2.223 & 0.026 & 0.129 & $\begin{array}{l}\text { Positive } \\
\text { significant } \\
\text { effect }\end{array}$ \\
\hline H6 & $\begin{array}{l}\text { Marketing } \\
\text { Performance }\end{array}$ & $<---$ & $\begin{array}{l}\text { process } \\
\text { Innovation }\end{array}$ & -0.153 & -2.626 & 0.009 & -0.149 & $\begin{array}{l}\text { Negative } \\
\text { significant } \\
\text { effect }\end{array}$ \\
\hline H7 & $\begin{array}{l}\text { Marketing } \\
\text { Performance }\end{array}$ & $<--$ & $\begin{array}{l}\text { marketing } \\
\text { Innovation }\end{array}$ & 0.523 & 5.145 & $* * *$ & 0.403 & $\begin{array}{l}\text { Positive } \\
\text { significant } \\
\text { effect }\end{array}$ \\
\hline H8 & $\begin{array}{l}\text { Marketing } \\
\text { Performance }\end{array}$ & $<--$ & $\begin{array}{l}\text { organizational } \\
\text { Innovation }\end{array}$ & -0.052 & -0.712 & 0.476 & -0.045 & $\begin{array}{l}\text { Insignificant } \\
\text { effect }\end{array}$ \\
\hline & $\begin{array}{l}\text { Marketing } \\
\text { Performance }\end{array}$ & $<---$ & $\begin{array}{l}\text { Social media } \\
\text { usage }\end{array}$ & -0.119 & -1.527 & 0.127 & -0.1 & $\begin{array}{l}\text { Insignificant } \\
\text { effect }\end{array}$ \\
\hline
\end{tabular}

The statistics show that all the path coefficient results seemed to be significant at $5 \%$ significance level, which means that all research hypotheses were supported with $p$ values less than 0.05 except for the research hypothesis number 8 (insignificant impact) (as showed in table 4). For the first hypothesis, it has been shown that social media usage has a significant positive direct impact on product innovation with a standardized estimate of 0.348 . This means that by using social media, organizations can discover and exploit new ideas from user-generated information, which will lead to favorable product innovation. For the second hypothesis, it has been shown that social media usage has a significant positive direct impact on process innovation with a standardized estimate of 0.508 . This means that when organizations depend on the information generated by users on social media, this will assist them to do business in an innovative manner. For the third hypothesis, it has been found that social media usage has the greatest significant positive direct impact on marketing innovation with a standardized estimate of 0.643 . This means that when organizations value the information and content generated by users, this will inspire them to take corrective actions in changing the promotion tools or the place or modifying the pricing strategy if necessary. For the fourth hypothesis, it has been found that social media usage has a significant positive direct impact on organizational innovation with a standardized estimate of 0.521 . This means that when organizations use social media to gain more insights from the shared information, this will help them to gain new ideas regarding new ways of dealing with external relations, adding new rules or make new decisions. For the fifth hypothesis, it has been indicated that product innovation has a significant positive direct impact on marketing performance with a standardized estimate of 0.129 . This means that new services or new customized offerings will positively support the organization's marketing performance such as enlarging their market share. For the sixth hypothesis, it has been found that the process has a significant negative impact on marketing performance with a standardized estimate of -0.149 . This means that innovation related to production methods, tasks, activities will lead to negative marketing performance. This is may be due to employees' resistance to change for example resisting to learn how to work with new equipment or to deal with new software. For the seventh hypothesis, it has been found that marketing innovation has a significant positive impact on marketing performance with a standardized estimate of 0.403 . This means that new and innovate changes in the marketing mix elements to create superior value, will generate high marketing performance. Whereas, for the eighth hypothesis, it has been found that organizational innovation has no significant impact on the marketing performance. This means that new rules or regulations in the workplace does not have a significant positive direct impact on the organization's marketing performance. This is may be because its impact is not noticeable like the other types of innovation or there is a lack of coordination among the different types of innovation. Finally, it has been found that there is no direct impact of social media usage on 
marketing performance, which highlights the crucial role of innovation.

\subsection{Indirect Effects}

This section examines the indirect effect of social media and marketing performance. As presented in table (5), there is indirect effect of social media usage on marketing performance.

\section{Table (5): Indirect Effects}

\begin{tabular}{|l|c|c|c|c|c|}
\hline \multicolumn{2}{|c|}{ Indirect Effects } & Estimate & $\begin{array}{c}\text { Standardized } \\
\text { Estimate }\end{array}$ & *p_value & \multicolumn{1}{c|}{ Result } \\
\hline $\begin{array}{l}\text { Marketing } \\
\text { Performance <--- }\end{array} \begin{array}{l}\text { Social media } \\
\text { usage }\end{array}$ & 0.244 & 0.205 & 0.012 & $\begin{array}{l}\text { Positive significant } \\
\text { Indirect effect }\end{array}$ \\
\hline
\end{tabular}

*Bias-corrected percentile method

As shown in table (5), there is indirect effect of social media usage on marketing performance with standardized estimate of 0.205 and $\mathrm{p}_{-}$value less than 0.05 .

\subsection{The Mediation Role}

This part presents the mediation role of the four innovation types between social media usage and marketing performance as presented in table (6)

Table (6): The Mediation Role

\begin{tabular}{|c|c|c|c|}
\hline The mediation of: & $\begin{array}{c}\text { the Necessary } \\
\text { conditions } \\
\text { (significant Direct } \\
\text { effect) }\end{array}$ & $\begin{array}{l}\text { the Sufficient condition } \\
\text { (significant Indirect } \\
\text { effect) }\end{array}$ & Results \\
\hline product Innovation & $\checkmark$ & $\checkmark$ & \multirow{3}{*}{ Fully mediate the relation } \\
\hline process Innovation & $\checkmark$ & $\checkmark$ & \\
\hline marketing Innovation & $\checkmark$ & $\checkmark$ & \\
\hline organizational Innovation & 区 & $\checkmark$ & No mediation \\
\hline
\end{tabular}

Table (6) identifies the role of the innovation types namely product, process, marketing and organizational innovation as mediators between social media usage and marketing performance. As shown in the table, the necessary and sufficient conditions are achieved in the relationship between them except for the organizational innovation. This means that product, process and marketing innovation plays fully mediation role however the organizational innovation does not play the mediation role between social media usage and marketing performance because the necessary conditions are not met.

Figure (2): The Final Research Model
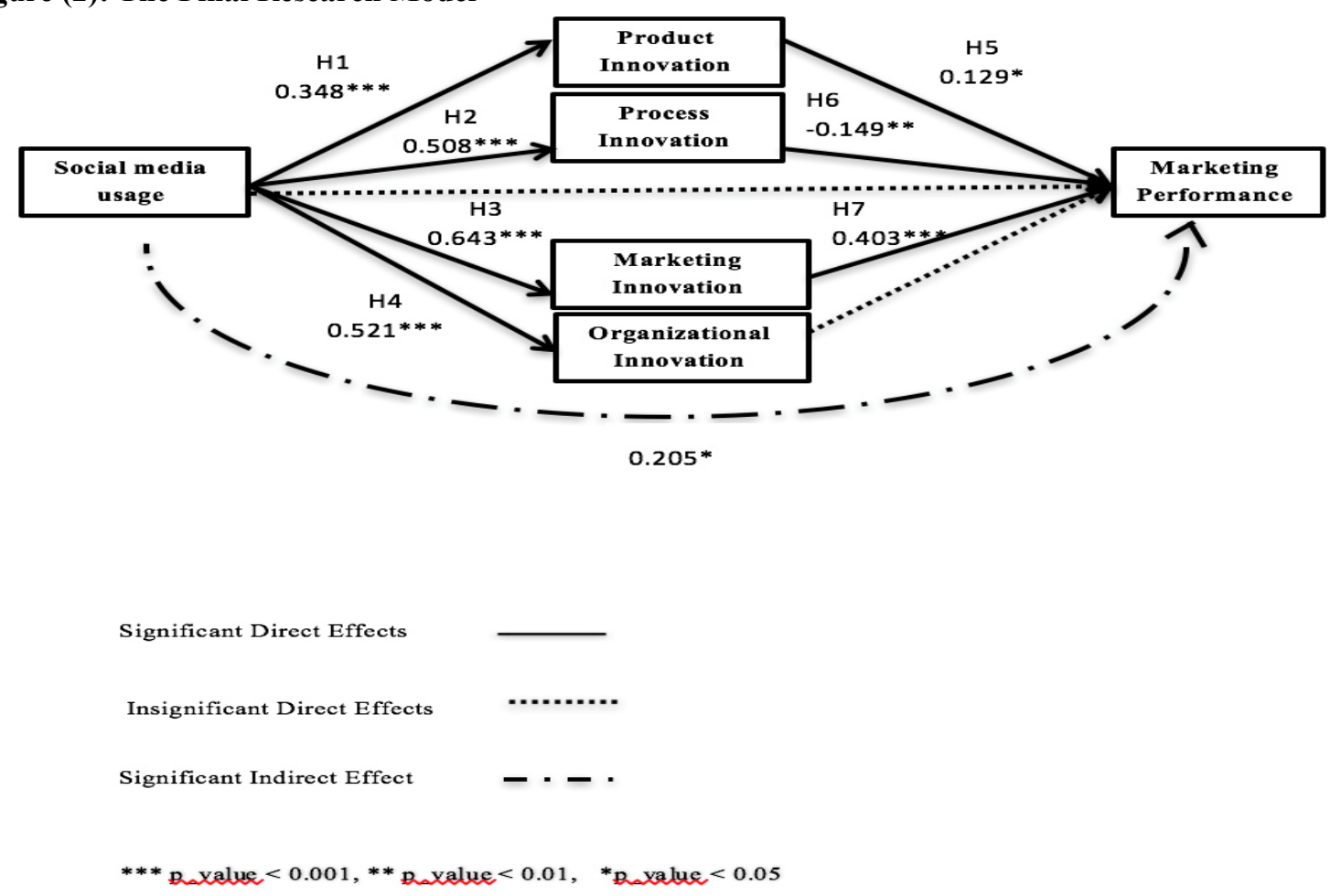


\section{Discussion and Conclusion}

An endless topic of interest for both manufacturing and service firms and researchers in the organizational field is innovation. All industries across the entire service sector are recognizing the critical role of innovation in improving their performances at general. Therefore, they seek to adopt the suitable tools which will allow them to speed up their firms' innovation levels and improve their marketing performance. Previous studies have indicated that social media usage pave the path to adopting innovation. This subsequently may have an impact on service firm's marketing performance. For such reason, this research fills-in the gap in literature between social media usage and firm's marketing performance via the different four types of innovation (Product, process, marketing and organizational) from the service firms' top management point of views. Unlike, past studies which captured and measured innovation as a uni-dimensional scale, this study contributed towards better understanding of the social media usage effect on innovation and the relative importance played by each of the innovation types in enhancing the service firm's marketing performance. Significant findings have been attained in this study. Social media usage with its two subsequent components knowledge exploration and exploitation has positive and direct impact on all of the innovation types with the greatest effect on the service firm's marketing innovation, followed by organizational, process and product innovation successively. This indicates that social media marketing information must be appreciated and sought by service providers and marketers such as the user-generated content which should be analyzed and nurtured by service firms to achieve an adapted marketing mix and take corrective actions such in deciding the most appropriate social media platforms to communicate with customers. Also, marketers can detect from the social media generated-user information and reviews the most creative approaches to improving their process innovation, adapting rules and decisions to develop customers' relationships and create the new ideas which will enable them to attain favorable features of product innovation.

In this study, the four types of innovation affected the service firms' marketing performance differently. The highest impact was that of the marketing innovation type on marketing performance which was significant and positive followed by product innovation. This indicates that marketing managers should introduce innovative modifications to the marketing mix and adopt marketing strategies and tactics to increase the market share, for example offering new innovative service ideas and retaining the loyal customer by providing new customized services. Unlike, past studies process innovation has a significant and negative effect on marketing performance. This may imply that innovation in the firms' production, tasks and activities levels may not be enforcing the same orientation of improving the marketing performance or is placed at a distant paradigm of implementation than the one executed in marketing and product innovations. This also, could be attributed to top management employees' resistance to change such as resisting the acquisition and development of specific technical skills to adapt with the changing market conditions. Findings indicated that organizational innovation effect on service firms' marketing performance is insignificant. This means that new rules in the service firm's do not have an impact on the organization's marketing performance, this may be due to lack of integration or coordination between the different adopted innovation types or may express that management concern for organizational innovation is set at a strategic level which is not integrated with the other functional or tactical levels. However, previous studies indicated that social media usage may generally affect the firm's performance, this study found that there is no direct impact of social media usage on marketing performance. This highlights the importance of the innovation types to make use of the social media's knowledge exploration and exploitation to enable service firms improve their marketing performance particularly marketing, product and process innovation due to their mediator role between SM usage and firm's marketing performance.

\section{Limitations and Future Directions}

This study focused on examining the impact of SM usage on the four types of innovation (product, process, marketing and organizational) separately from the top management level. Therefore, it would be useful if further studies would examine the interrelationships among the innovation types and their impact on marketing performance of service firms and consider a comparative evaluation between the management levels in fostering the different innovation types. Additionally, this study used a convenience sampling technique due to the unavailability of the sampling frame. Future studies may use probability sampling approaches to generalize over the total population. Finally, this study was focused on the firm's marketing performance in the private service sector, other studies may include the effect of SM usage on other types of firm's performance to provide more insights and focus on specific industries in the service sector.

\section{References}

Afriyie, S., Du, J., \& Ibn Musah, A. (2019). Innovation and marketing performance of SME in an emerging economy: the moderating effect of transformational leadership. Journal Of Global Entrepreneurship Research, 9(1). doi: 10.1186/s40497-019-0165-3

Akgün, A., Ince, H., Imamoglu, S., Keskin, H., \& Kocoglu, İ. (2013). The mediator role of learning capability 
and business innovativeness between total quality management and financial performance. International Journal Of Production Research, 52(3), 888-901. doi: 10.1080/00207543.2013.843796

Aksoy, H. (2017). How do innovation culture, marketing innovation and product innovation affect the market performance of small and medium-sized enterprises (SMEs)?. Technology In Society, 51, 133-141. doi: 10.1016/j.techsoc.2017.08.005

Aksoy, H. (2017). How do innovation culture, marketing innovation and product innovation affect the market performance of small and medium-sized enterprises (SMEs)?. Technology In Society, 51, 133-141. doi: 10.1016/j.techsoc.2017.08.005

Alrowwad, A., Abualoush, S., \& Masa'deh, R. (2020). Innovation and intellectual capital as intermediary variables among transformational leadership, transactional leadership, and organizational performance. Journal Of Management Development, 39(2), 196-222. doi: 10.1108/jmd-02-2019-0062

Anderson, J., \& Gerbing, D. (1988). Structural equation modeling in practice: A review and recommended twostep approach. Psychological Bulletin, 103(3), 411-423. doi: 10.1037/0033-2909.103.3.411

Ando, L. (2021). Council Post: Innovation Trends In 2021: Why Trust Is Now More Important Than Ever. Retrieved 19 August 2021, from https://www.forbes.com/sites/forbestechcouncil/2021/02/17/innovationtrends-in-2021-why-trust-is-now-more-important-than-ever/

Anning Dorson, T. (2017). Innovation development in service firms: a three-model perspective. International Journal Of Services And Operations Management, 28(1), 64. doi: 10.1504/ijsom.2017.10006274

Atalay, M., Anafarta, N., \& Sarvan, F. (2013). The Relationship between Innovation and Firm Performance: An Empirical Evidence from Turkish Automotive Supplier Industry. Procedia - Social And Behavioral Sciences, 75, 226-235. doi: 10.1016/j.sbspro.2013.04.026

Barney, J. (1991). Firm Resources and Sustained Competitive Advantage. Journal Of Management, 17(1), 99120. doi: $10.1177 / 014920639101700108$

Bartlett, M. (1951). The Effect of Standardization on a $\chi 2$ Approximation in Factor Analysis. Biometrika, 38(3/4), 337. doi: $10.2307 / 2332580$

Bhatti, S., Santoro, G., Khan, J., \& Rizzato, F. (2021). Antecedents and consequences of business model innovation in the IT industry. Journal Of Business Research, 123, 389-400. doi: 10.1016/j.jbusres.2020.10.003

Bhimani, H., Mention, A., \& Barlatier, P. (2019). Social media and innovation: A systematic literature review and future research directions. Technological Forecasting And Social Change, 144, 251-269. doi: 10.1016/j.techfore.2018.10.007

Buenechea-Elberdin, M. (2017). Structured literature review about intellectual capital and innovation. Journal Of Intellectual Capital, 18(2), 262-285. doi: 10.1108/jic-07-2016-0069

CAPMAS (Central Agency for Public Mobilization and Statistics)(2021). Retrieved 21 June 2021, from https://www.capmas.gov.eg/Pages/Economicnew.aspx?page_id=2029

Corral de Zubielqui, G., \& Jones, J. (2020). How and when social media affects innovation in start-ups. A moderated mediation model. Industrial Marketing Management, 85, 209-220. doi: 10.1016/j.indmarman.2019.11.006

Datta, A. (2011). Exterior Sourcing and Technology Distinctness as Indicators for Radical Innovations: Evidence from Patents in Information Technology Industry. Technology And Investment, 02(03), 193-201. doi: 10.4236/ti.2011.23020

Dong, J., \& Wu, W. (2015). Business value of social media technologies: Evidence from online user innovation communities. The Journal Of Strategic Information Systems, 24(2), 113-127. doi: 10.1016/j.jsis.2015.04.003

Dost, M., Badir, Y., Sambasivan, M., \& Umrani, W. (2020). Open-and-closed process innovation generation and adoption: Analyzing the effects of sources of knowledge. Technology In Society, 62, 101309. doi: 10.1016/j.techsoc.2020.101309

Dwivedi, Y., Ismagilova, E., Hughes, D., Carlson, J., Filieri, R., \& Jacobson, J. et al. (2020). Setting the future of digital and social media marketing research: Perspectives and research propositions. International Journal Of Information Management, 102168. https://doi.org/10.1016/j.ijinfomgt.2020.102168

Ferraris, A., Santoro, G., \& Bresciani, S. (2017). Open innovation in multinational companies' subsidiaries: the role of internal and external knowledge. European J. Of International Management, 11(4), 452. doi: 10.1504/ejim.2017.10006514

Ferraz, I., \& de Melo Santos, N. (2016). The relationship between service innovation and performance: a bibliometric analysis and research agenda proposal. RAI Revista De Administração E Inovação, 13(4), 251260. doi: 10.1016/j.rai.2016.09.005

Freixanet, J., Braojos, J., Rialp-Criado, A., \& Rialp-Criado, J. (2021). Does international entrepreneurial orientation foster innovation performance? The mediating role of social media and open innovation. The International Journal Of Entrepreneurship And Innovation, 22(1), 33-44. doi: 10.1177/1465750320922320 
Gunday, G., Ulusoy, G., Kilic, K., \& Alpkan, L. (2011). Effects of innovation types on firm performance. International Journal Of Production Economics, 133(2), 662-676. doi: 10.1016/j.ijpe.2011.05.014

Gupta, R. (2021). The need for global access to biomedical innovations during pandemics. Nature Biotechnology, 39(6), 664-666. doi: 10.1038/s41587-021-00942-3

Hair, J., Black, W., Babin, B., \& Anderson, R. (2010). Multivariate data analysis (7th ed.). New Jersey: Prentice.

Hair, J., Lukas, B., Roberts, K., \& Lee-Lukas, S. (2014). Marketing research. North Ryde, NSW: McGraw-Hill Education.

Hameed, W., Basheer, M., Iqbal, J., Anwar, A., \& Ahmad, H. (2018). Determinants of Firm's open innovation performance and the role of R \& D department: an empirical evidence from Malaysian SME's. Journal Of Global Entrepreneurship Research, 8(1). doi: 10.1186/s40497-018-0112-8

Hardwick, J., \& Anderson, A. (2019). Supplier-customer engagement for collaborative innovation using video conferencing: A study of SMEs. Industrial Marketing Management, 80, 43-57. doi: 10.1016/j.indmarman.2019.02.013

Hassan, M. U., Shaukat, S., Nawaz, M. S., \& Naz, S. (2013). Effects of innovation types on firm performance: An empirical study on Pakistan's manufacturing sector. Pakistan Journal of Commerce and Social Sciences, 7, 243.

Herhausen, D., Ludwig, S., Grewal, D., Wulf, J., \& Schoegel, M. (2019). Detecting, Preventing, and Mitigating Online Firestorms in Brand Communities. Journal Of Marketing, 83(3), 1-21. doi: $10.1177 / 0022242918822300$

Kaplan, A., \& Haenlein, M. (2010). Users of the world, unite! The challenges and opportunities of Social Media. Business Horizons, 53(1), 59-68. doi: 10.1016/j.bushor.2009.09.003

Khan, H., \& Khan, Z. (2021). The efficacy of marketing skills and market responsiveness in marketing performance of emerging market exporting firms in advanced markets: The moderating role of competitive intensity. International Business Review, 101860. doi: 10.1016/j.ibusrev.2021.101860

Kiron D, Palmer D, Phillips AN, et al. (2013) Social business: shifting out of first gear. MIT Sloan Management Review 55(1): 1-29.

Kohlbacher, M. (2013). The Impact of Dynamic Capabilities through Continuous Improvement on Innovation: the Role of Business Process Orientation. Knowledge And Process Management, 20(2), 71-76. doi: $10.1002 / \mathrm{kpm} .1405$

Kozlenkova, I., Samaha, S., \& Palmatier, R. (2013). Resource-based theory in marketing. Journal Of The Academy Of Marketing Science, 42(1), 1-21. doi: 10.1007/s11747-013-0336-7

Lager, T. (2017). A conceptual analysis of conditions for innovation in the process industries and a guiding framework for industry collaboration and further research. International Journal Of Technological Learning, Innovation And Development, 9(3), 189. doi: 10.1504/ijtlid.2017.10008245

Marchand, A., Hennig-Thurau, T., \& Flemming, J. (2020). Social media resources and capabilities as strategic determinants of social media performance. International Journal Of Research In Marketing. doi: 10.1016/j.ijresmar.2020.09.011

Mention, A., Barlatier, P., \& Josserand, E. (2019). Using social media to leverage and develop dynamic capabilities for innovation. Technological Forecasting And Social Change, 144, 242-250. doi: 10.1016/j.techfore.2019.03.003

OECD (Organization for Economic Cooperation and Development)/Eurostat 2015. Guidelines for Collecting and Interpreting Innovation Data - The Oslo Manual, 3rd edn. Paris: OECD.

Oyewobi, L., Olorunyomi, O., Jimoh, R., \& Rotimi, J. (2021). Impact of social media usage on performance of construction businesses (CBs) in Abuja, Nigeria. Journal Of Financial Management Of Property And Construction, 26(2), 257-278. doi: 10.1108/jfmpc-05-2020-0042

Parveen, F., Jaafar, N., \& Ainin, S. (2016). Social media's impact on organizational performance and entrepreneurial orientation in organizations. Management Decision, 54(9), 2208-2234. doi: 10.1108/md-082015-0336

Patroni, J., von Briel, F., \& Recker, J. (2020). Unpacking the social media-driven innovation capability: How consumer conversations turn into organizational innovations. Information \& Management, 103267. doi: 10.1016/j.im.2020.103267

Payne, A., Storbacka, K., \& Frow, P. (2008). Managing the co-creation of value. Journal Of The Academy Of Marketing Science, 36(2008), 83-96.doi: 10.1007/s11747-007-0070-0

Pérez-González, D., Trigueros-Preciado, S., \& Popa, S. (2017). Social Media Technologies' Use for the Competitive Information and Knowledge Sharing, and Its Effects on Industrial SMEs' Innovation. Information Systems Management, 34(3), 291-301. doi: 10.1080/10580530.2017.1330007

Polder, M., Leeuwen, G., Mohnen, P., \& Raymond, W. (2010). Product, Process and Organizational Innovation: Drivers, Complementarity and Productivity Effects. SSRN Electronic Journal. doi: 10.2139/ssrn.1626805

Rosenbaum, M., Otalora, M., \& Ramírez, G. (2017). How to create a realistic customer journey map. Business 
Horizons, 60(1), 143-150. doi: 10.1016/j.bushor.2016.09.010

Sharma, N., \& Patterson, P. (1999). The impact of communication effectiveness and service quality on relationship commitment in consumer, professional services. Journal Of Services Marketing, 13(2), 151170. doi: $10.1108 / 08876049910266059$

Vaona, A., \& Pianta, M. (2007). Firm Size and Innovation in European Manufacturing. Small Business Economics, 30(3), 283-299. doi: 10.1007/s11187-006-9043-9

Varis, M., \& Littunen, H. (2010). Types of innovation, sources of information and performance in entrepreneurial SMEs. European Journal Of Innovation Management, 13(2), 128-154. doi: $10.1108 / 14601061011040221$

Wang, Y., Hong, A., Li, X., \& Gao, J. (2020). Marketing innovations during a global crisis: A study of China firms' response to COVID-19. Journal Of Business Research, 116, 214-220. doi: 10.1016/j.jbusres.2020.05.029

Yeh - Yun Lin, C., \& Yi - Ching Chen, M. (2007). Does innovation lead to performance? An empirical study of SMEs in Taiwan. Management Research News, 30(2), 115-132. doi: 10.1108/01409170710722955

Zaefarian, G., Forkmann, S., Mitręga, M., \& Henneberg, S. (2017). A Capability Perspective on Relationship Ending and Its Impact on Product Innovation Success and Firm Performance. Long Range Planning, 50(2), 184-199. doi: $10.1016 /$ j.lrp.2015.12.023

Zhang, H., Gupta, S., Sun, W., \& Zou, Y. (2020). How social-media-enabled co-creation between customers and the firm drives business value? The perspective of organizational learning and social Capital. Information \& Management, 57(3), 103200. doi: 10.1016/j.im.2019.103200 